\title{
The Physicochemical Properties of Soil and Functional Characteristics of Sward on a Grass Airstrip
}

\author{
Kazimierz Grabowski ${ }^{1 *}$, Jan Pawluczuk ${ }^{2}$ Stefan Grzegorczyk $^{1}$, \\ Andrzej Lachacz ${ }^{2}$, Krystyna Grabowska ${ }^{3}$ \\ ${ }^{1}$ University of Warmia and Mazury in Olsztyn, Faculty of Environmental Management and Agriculture, \\ Department of Grassland and Green Space Management, \\ Pl. Lodzki 1, 10-727 Olsztyn, Poland \\ ${ }^{2}$ University of Warmia and Mazury in Olsztyn, Faculty of Environmental Management and Agriculture, \\ Department of Soil Science and Land Reclamation, \\ Plac Łódzki 3, 10-727 Olsztyn, Poland \\ ${ }^{3}$ University of Warmia and Mazury in Olsztyn, Faculty of Environmental Management and Agriculture, \\ Department of Water, Climate, and Environmental Management, \\ Plac Łódzki 2, 10-727 Olsztyn, Poland
}

Received: 12 September 2016

Accepted: 3 November 2016

\begin{abstract}
This paper presents the physicochemical properties of soil and functional characteristics of sward on a grass runway of the airport in Gryźliny near Olsztyn (NE Poland). Soil samples for physicochemical analyses were collected from the surface layer $(5-15 \mathrm{~cm})$, and the overwintering success, density, color, and overall quality of the sward at 12 sites were graded on a nine-point scale in 2010-13. Long-term operation of the airstrip influenced the physical properties (compaction) of the substrate and diversified the functional characteristics of sward. The soil was classified according to Polish Soil Classification 2011 as proper rusty soil, and it was classified according to IUSS Working Group WRB 2014 as Brunic Arenosol (Dystric). The evaluated soil had high content of organic matter determined as loss-on-ignition ranging from 17.3 to $18.5 \%$, which is a typical feature of sod layers. The content of macronutrients $\left(\mathrm{N}-\mathrm{NO}_{3}, \mathrm{P}, \mathrm{K}, \mathrm{Mg}\right)$ as well as selected micronutrients $(\mathrm{Cu}, \mathrm{Zn})$ was low. Nutritional status of the studied soil was caused by its sandy texture. The analyzed sward was characterized by moderate overwintering success, good density (in particular in fall), green and fresh green color, and satisfactory-to-good visual merit. The condition of the sward covering the runway was affected by the physicochemical properties of the soil as well as aircraft operations (take-offs and landings), applied management practices, and weather conditions during the study.
\end{abstract}

Keywords: physicochemical soil properties, sandy soils, functional characteristics of sward, grass airstrip

*e-mail: kazikg@uwm.edu.pl 


\section{Introduction}

The growing demand for private and business aviation has created new opportunities for the development of grass airstrips [1]. Grass-covered surfaces are encountered mostly in sport aviation centers and low-traffic airports. Swards covering runways should be characterized by dense and leveled surface, high resistance to loading (in particular during take-offs and landings, even under difficult weather conditions), and high regeneration capacity [2].

Sward quality is determined by numerous factors, including the type of substrate (soil), species composition of sward, intensity of use, and the applied treatments [310]. Sward degradation in grass runways is often caused by excessive compaction of the substrate, which changes its physical properties, decreases porosity and permeability, eliminates grass species, loosens the turf, and decreases its visual merit [2]. Numerous papers have investigated the maintenance of grass surfaces on sports facilities, but an insufficient number of papers have looked at maintaining vegetation cover on grassy airstrips and other surfaces vulnerable to stressful conditions, e.g., roadsides [11]. Due to high qualitative requirements for such surfaces and the concurrent stresses experienced by grassy airstrips, it is assumed that only carefully selected multi-species assemblages can meet such requirements [12]. The surfaces of airports play many functions, not only useful ones but also environmental, like preventing soil erosion and filtering runoff water. Also, the role of grassy surfaces in the storage of organic carbon in soil is also emphasized [13]. Moreover, the aesthetic (landscape) role is also of great importance regarding the area of airports [14].

Maintaining grass airstrip requires regular mowing, which is more intensive than in the case of other surfaces and affects plant diversity. This kind of vegetation is affected by soil properties [15]. Specific grass species are exposed to constant stress related to not only mowing but also to the motion of aircraft [16].

The aim of this study was to determine the physicochemical properties of the soil and the functional characteristics of a grass runway at Gryźliny airport.

\section{Materials and Methods}

The experiment was carried out in 2010-13 on the runway of a grass airport in Gryźliny, approximately $20 \mathrm{~km}$ south of Olsztyn in northeastern Poland. The airport was built in 1937-38 and it was upgraded and used for basic glider training after World War II. In 2007, the site was listed as a multi-purpose airport, including as a landing zone for emergency helicopters, in the Register of Landing Zones of the Civil Aviation Authority [17]. The airport was fenced, and the runway $(800 \times 60 \mathrm{~m})$ was labeled in accordance with the relevant regulations [18].

Soil samples for physicochemical analyses were collected from topsoil (depth of 5-15 cm) at three representative sampling sites (at the beginning, in the middle, and at the end of the runway; Fig. 1. Soil analyses were carried out in air-dry soil samples after sieving through a $2.0 \mathrm{~mm}$ mesh using standard soil laboratory methods [19]. Soil texture of finer fractions (diameter less than $2.00 \mathrm{~mm}$ ) was analysed using the laser diffraction method with a Malvern Mastersizer 2000. Organic matter content (LOI) was determined as the weight lost during roasting in a muffle furnace at a temperature of $550^{\circ} \mathrm{C}[20]$. Total organic carbon (TOC) content was measured with a spectrophotometer after oxidation with potassium dichromate, and soil reaction in $\mathrm{KCl}$ and $\mathrm{H}_{2} \mathrm{O}$ (potentiometrically) [19]. Soil moisture content was determined in a dryer, and bulk density (gc) was determined in $100 \mathrm{~cm}^{3}$ steel cylinders by drying samples at $105^{\circ} \mathrm{C}$. Specific gravity (gw) was calculated using the regression equation [21]:

$$
\mathrm{gW}=1.451+0.011(100-\mathrm{LOI}) \quad\left(\mathrm{Mg} \mathrm{m}^{-3}\right)
$$

Total porosity (fc) was calculated from the following equation:

$$
\mathrm{fc}=1-(\mathrm{gc} / \mathrm{gw}) \times 100 \quad(\% \mathrm{vol} .) .
$$

Soil compaction was diagnosed with a cone penetrometer. In this determination, a cone was introduced into the sod layer down to $9 \mathrm{~cm}$. Salinity was determined by flame photometry. The concentrations of available macronutrients and micronutrients ( $\mathrm{P}, \mathrm{K}, \mathrm{Mg}, \mathrm{Cu}, \mathrm{Mn}, \mathrm{Fe}$, and $\mathrm{Zn}$ ) were determined in $0.5 \mathrm{~mol} \mathrm{HCl} \mathrm{dm}^{-3}$ [20]. The analyses were performed in duplicate and the results were expressed as an arithmetic mean on an oven-dried soil weight basis (dried at $105^{\circ} \mathrm{C}$ ).

In 2010-13, the following parameters were evaluated at 12 representative sites of the grass runway in accordance with the methodology recommended by the Research Center for Cultivar Testing (COBORU) [22]: overwintering success (spring), density, color, and overall quality of the sward (spring, summer, and fall) on a ninepoint scale (1 unacceptable, 5 - satisfactory, 9 - highly desirable). The minimum required score for sward density and overall quality was 5.0 points [23-24].

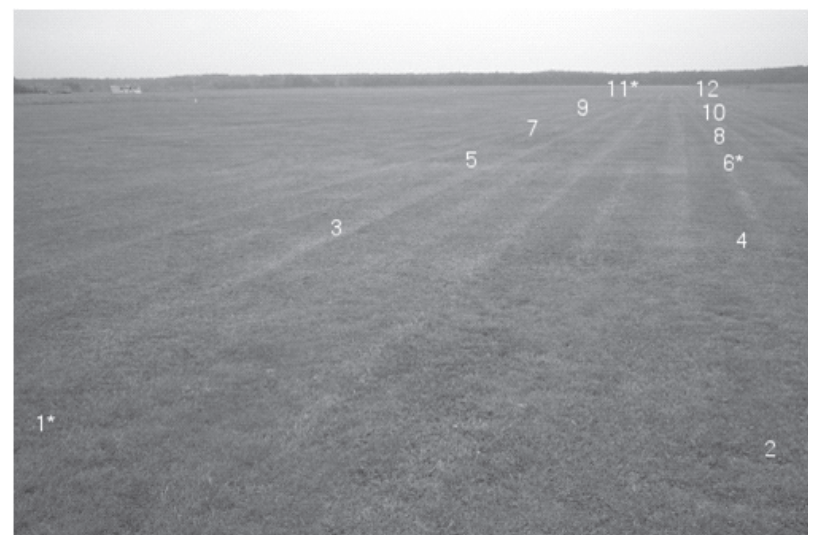

Fig. 1. Image of the Gryźliny airport grass runway. (1-12: study sites, *: soil sampling sites). 
In 2010-13, Yara Mila Complex mineral fertilizer ( $\mathrm{N}$ $12 \%+\mathrm{P} 11 \%+\mathrm{K} 18 \%+\mathrm{Mg} 2.7 \%+\mathrm{S} 8 \%+$ addition of $\mathrm{B}, \mathrm{Fe}, \mathrm{Mn}$, and $\mathrm{Zn}$ ) was applied twice a year: in early spring $\left(250 \mathrm{~kg} \mathrm{ha}^{-1}\right)$ and in fall $\left(150 \mathrm{~kg} \mathrm{ha}^{-1}\right)$, whereas a nitrogen fertilizer was applied at the beginning of the growing season and then after every third mowing at the rate of 20-30 $\mathrm{kg} \mathrm{N} \mathrm{ha}^{-1}$. Sward was mowed at least once a week in May and June, and then every two weeks, to a height of 4-6 cm. Annual treatments were limited to smoothing (dragging) and rolling in spring, whereas sprinkling irrigation was not applied even during drought.

The grassy airstrip was established in the 1970s by plowing and sowing a grass mixture. During the period of investigation the dominant plant composition was as follows: Festuca ovina L. 32-43\%, Festuca rubra L. 3036\%, Poa pratensis L. 12-17\%, and Agrostis capillaris L. $10-14 \%$.

Weather conditions during the study are presented in Table 1. In 2010-13, weather conditions were generally favorable for plant growth and development. High ambient temperatures during the growing season were accompanied by above-average precipitation (excluding April and May 2011, May and August 2012, and April, May, and August 2013). Average ambient temperature and total precipitation in each year of the study exceeded the multi-year average (Table 1). Winter temperatures ranged from relatively high in December 2011 and 2013 to low in January and February of all experimental years, and March 2013 (average ambient temperature was $-3.5^{\circ} \mathrm{C}$ ).

\section{Results and Discussion}

The grass runway was constructed on a rusty soil developed from loose, coarse-grained sand with substantial admixture of gravel fraction. Average content of gravel fraction was $20.3 \%$ of the bulk soil samples. The thickness of the humus layer ranged from 15 to $25 \mathrm{~cm}$ (which meets ochric horizon criteria). Lying below the sideric horizon was composed of yellowish-brown, slightly loamy sand with slightly acidic $\mathrm{pH}$ [25]. Due to sandy texture the soilwater regime can be classified as permanently dry [26].

Soil granulometric composition of the grass runway is presented in Table 2. According to the Polish Society of Soil Science [27], the topsoil layer of the grass airstrip $(5-15 \mathrm{~cm})$ is composed of loose sand. In topsoil, the content of skeleton particles $(\varphi>2.0 \mathrm{~mm})$ was estimated at $19-21 \%$, sand fraction (mostly coarse and very coarse) at $86.70-92.97 \%$, silt fraction at $7.03-12.66 \%$, and clay fraction at up to $0.64 \%$. Based on its granulometric composition, the soil was classified as very light soil with a moderate content of skeleton particles [27]. Such soils are characterized by extremely low retention of plants' available water [26]. Their water budget is based mainly on rainfall. Because of higher rainfalls in the growing period during the investigated years (2010-13), grasses did not suffer water deficiency (Table 1). However, in the other years this fact should be taken into consideration and an irrigation system should be installed.

The physical properties of the analyzed soil were characteristic of loose and slightly loamy sands that form proper rusty soils [25]. According to the IUSS Working Group WRB (2014), the studied soil was classified as

Table 1. Mean monthly ambient temperatures and total precipitation during the study.

Source: Meteorological Station in Tomaszkowo.

\begin{tabular}{|c|c|c|c|c|c|c|c|c|c|c|}
\hline \multirow{2}{*}{ Month } & \multicolumn{4}{|c}{ Average air temperature $\left({ }^{\circ} \mathrm{C}\right)$} & \multicolumn{5}{c|}{ Precipitation $(\mathrm{mm})$} \\
\cline { 2 - 13 } & 2010 & 2011 & 2012 & 2013 & $1961-2000$ & 2010 & 2011 & 2012 & 2013 & $1961-2000$ \\
\hline I & -9.0 & -1.5 & -1.7 & -4.6 & -2.3 & 19.4 & 34.8 & 61.8 & 44.1 & 25.2 \\
\hline II & -3.0 & -5.8 & -7.5 & -1.1 & -1.5 & 22.5 & 36.9 & 27.7 & 22.6 & 23.6 \\
\hline III & 2.1 & 1.6 & 3.0 & -3.5 & 1.0 & 36.7 & 16.3 & 24.7 & 18.1 & 28.7 \\
\hline IV & 8.1 & 9.1 & 7.8 & 5.9 & 7.5 & 18.2 & 22.5 & 73.1 & 28.5 & 40.8 \\
\hline V & 12.0 & 13.1 & 13.4 & 14.8 & 12.7 & 131.9 & 51.1 & 51.7 & 54.5 & 66.5 \\
\hline VI & 16.4 & 17.1 & 15.0 & 17.5 & 16.3 & 84.8 & 81.7 & 103.2 & 61.2 & 65.2 \\
\hline VII & 21.1 & 17.9 & 19.0 & 18.0 & 17.1 & 80.4 & 202.8 & 121.0 & 121.9 & 89.1 \\
\hline VIII & 19.3 & 17.6 & 17.7 & 17.4 & 17.1 & 95.3 & 82.1 & 45.1 & 37.6 & 67.9 \\
\hline IX & 12.0 & 14.1 & 13.5 & 11.3 & 12.1 & 40.5 & 67.5 & 45.7 & 101.1 & 32.6 \\
\hline X & 5.0 & 8.3 & 7.4 & 8.9 & 7.9 & 24.1 & 29.5 & 68.5 & 16.0 & 42.7 \\
\hline XI & 4.4 & 3.1 & 4.9 & 5.0 & 2.3 & 121.4 & 14.1 & 45.2 & 18.0 & 40.0 \\
\hline XII & -6.8 & 2.3 & -3.5 & 2.3 & -1.4 & 57.2 & 25.8 & 11.6 & 27.7 & 29.3 \\
\hline I-XII & 6.8 & 8.1 & 7.4 & 7.6 & 7.4 & 732.4 & 665.1 & 679.3 & 551.3 & 551.6 \\
\hline IV-IX & 14.8 & 14.8 & 14.4 & 14.1 & 13.8 & 451.1 & 507.7 & 439.8 & 404.8 & 362.1 \\
\hline
\end{tabular}


Brunic Arenosol (Dystric) [28]. The evaluated soil had high content of organic matter determined as loss-on-ignition ranging from 17.3 to $18.5 \%$, which is a typical feature of the sod layer (Table 3). In the case of a grass airstrip, soil physical properties of surface layer, including sod strength and penetration resistance, are of great importance [29].

Table 2. Granulometric composition of topsoil $(5-15 \mathrm{~cm})$ on the grass runway of Gryźliny airport.

\begin{tabular}{|c|c|c|c|c|c|c|c|c|}
\hline \multirow{3}{*}{$\begin{array}{c}\text { Sampling site } \\
\text { number }\end{array}$} & \multicolumn{7}{|c|}{ Fraction content $(\%)$} & \multirow{3}{*}{$\begin{array}{c}\text { Soil texture } \\
\text { acc.PSSS* } \\
{[27]}\end{array}$} \\
\hline & \multicolumn{7}{|c|}{ Particle diameter (mm) } & \\
\hline & $>2.0$ & $2.0-0.5$ & $0.5-0.25$ & $0.25-0.05$ & $0.05-0.02$ & $0.02-0.002$ & $<0.002$ & \\
\hline 1 & 21 & 56.91 & 14.51 & 20.95 & 5.14 & 2.49 & 0.00 & $\mathrm{pl}$ \\
\hline 3 & 21 & 55.26 & 12.30 & 23.51 & 5.30 & 3.54 & 0.09 & $\mathrm{pl}$ \\
\hline 6 & 20 & 43.57 & 25.67 & 21.34 & 6.50 & 2.92 & 0.00 & $\mathrm{pl}$ \\
\hline 7 & 19 & 39.75 & 23.64 & 23.31 & 7.37 & 5.29 & 0.64 & ps \\
\hline 9 & 20 & 51.02 & 21.50 & 20.45 & 5.01 & 2.02 & 0.00 & $\mathrm{pl}$ \\
\hline 11 & 21 & 46.83 & 23.56 & 20.10 & 6.65 & 2.86 & 0.00 & $\mathrm{pl}$ \\
\hline Mean & 20.33 & 48.89 & 20.20 & 21.61 & 5.99 & 3.19 & 0.12 & \\
\hline
\end{tabular}

*pl - loose sand; ps - slightly loamy sand

Table 3. Physicochemical properties of topsoil $(5-15 \mathrm{~cm})$ on the grass runway of Gryźliny airport.

\begin{tabular}{|c|c|c|c|c|}
\hline \multirow{2}{*}{ Specification } & \multicolumn{3}{|c|}{ Sampling sites } & \multirow{2}{*}{ Mean } \\
\hline & 1 & 6 & 11 & \\
\hline Loss-on-ignition (\%) & 17.40 & 18.50 & 17.30 & 17.73 \\
\hline Bulk density of dry soil $\left(\mathrm{Mg} \mathrm{m}^{-3}\right)$ & 1.540 & 1.570 & 1.580 & 1.560 \\
\hline Specific density $\left(\mathrm{Mg} \mathrm{m}^{-3}\right)$ & 2.360 & 2.348 & 2.361 & 2.356 \\
\hline Total porosity $(\%)$ & 34.8 & 33.1 & 33.1 & 33.7 \\
\hline Penetration resistance $(\mathrm{MPa}) *$ & 3.20 & 3.67 & 4.17 & 3.68 \\
\hline Sample-time moisture ( $\%$ vol.) & 27.3 & 27.3 & 27.8 & 27.5 \\
\hline $\mathrm{pH}_{\mathrm{KCl}}$ & 4.74 & 5.55 & 5.23 & 5.17 \\
\hline $\mathrm{pH}_{\mathrm{H} 2 \mathrm{O}}$ & 5.76 & 6.32 & 6.17 & 6.08 \\
\hline TOC (\%) & 3.16 & 3.36 & 2.98 & 3.17 \\
\hline Salinity $\left(\mathrm{g} \mathrm{kg}^{-1}\right)$ & 0.06 & 0.06 & 0.04 & 0.05 \\
\hline \multicolumn{5}{|c|}{ Plant available components $\left(\mathrm{mg} \mathrm{kg}^{-1}\right)$} \\
\hline $\mathrm{N}-\mathrm{NO}_{3}$ & 7.0 & 2.0 & 2.0 & 3.7 \\
\hline $\mathrm{P}$ & 12.0 & 20.0 & 16.0 & 16.0 \\
\hline K & 45.0 & 21.0 & 10.0 & 25.3 \\
\hline $\mathrm{Ca}$ & 406.0 & 642.0 & 433.0 & 493.7 \\
\hline $\mathrm{Na}$ & 8.0 & 8.0 & 11.0 & 10.7 \\
\hline $\mathrm{Mg}$ & 18.0 & 23.0 & 16.0 & 19.0 \\
\hline $\mathrm{Mn}$ & 132 & 188 & 211 & 177 \\
\hline $\mathrm{Cl}$ & 2.0 & 2.0 & 1.0 & 1.7 \\
\hline $\mathrm{Cu}$ & 10.8 & 2.6 & 5.9 & 6.4 \\
\hline $\mathrm{Zn}$ & 3.5 & 2.7 & 3.7 & 3.3 \\
\hline $\mathrm{Fe}$ & 1480 & 1600 & 1520 & 1533 \\
\hline
\end{tabular}

*for a 0-9 cm soil layer 
Table 4. Overwintering success of the sward covering the runway.

\begin{tabular}{|c|c|c|c|c|}
\hline Year & Mean & Minimum & Maximum & $\begin{array}{c}\text { Coefficient of } \\
\text { variation (\%) }\end{array}$ \\
\hline 2010 & 5.7 & 4 & 7 & 15.7 \\
\hline 2011 & 5.2 & 3 & 7 & 24.5 \\
\hline 2012 & 5.4 & 4 & 9 & 20.0 \\
\hline 2013 & 7.4 & 6 & 9 & 13.4 \\
\hline Mean & 5.9 & 3 & 8 & 23.1 \\
\hline
\end{tabular}

Soil compaction caused by aircraft operation as well as motions connected with sod maintenance (mowing, dragging, rolling, etc.) influence water infiltration into soil. Enhanced soil compaction influences the ability of soil to transfer liquids and gases, therefore it is considered a degradable factor [30]. However, in the case of a grass airstrip the maintenance of a stable surface necessary for takeoff and landing of aircraft is deciduous. Therefore, higher soil compaction than in "normal" grassland is acceptable.

The dry bulk density of topsoil was high, in the range of 1.54-1.58 $\mathrm{Mg} \mathrm{m}^{-3}$, which points to the high compaction of topsoil on the grass runway. It is assumed that in sandy soils root penetration will be limited when dry soil bulk density approaches $1.75 \mathrm{Mg} \mathrm{m}^{-3}$ [31]. Soil porosity was determined at 33.1-34.8\%, which marks the upper limit in slightly loamy sands. Soil porosity depends on various factors, including particle size distribution (granulometric composition), humus content, activity of soil mesofauna and plant roots, management practices, fertilization, and weather conditions [32]. Penetration resistance exceeded 3.0 $\mathrm{MPa}$ in the sod layer $(0-9 \mathrm{~cm})$, which indicates good conditions for aircraft operations. It is assumed that values higher than $2.5 \mathrm{MPa}$ are indicative of restricted root growth.

The physical properties of sandy soil analyzed under long-term grassy cover and under airport operation should be regarded as appropriate. It is assumed that the long-term grassy cover promotes pore rigidity and mechanical soil resilience, thus optimizing soil physical and physicochemical properties and functions [33].

The $\mathrm{pH}$ of topsoil in the grass runway is relatively stable, ranging from acidic to slightly acidic $(\mathrm{pH}$ in $\mathrm{H}_{2} \mathrm{O}$ from 5.76 to 6.32). Soil fertility is determined by humus content as well as the contents of plant-available macronutrients (Table 3). The evaluated soil was deficient in nitrate nitrogen, phosphorus, potassium, magnesium, copper, and zinc [34]. Generally, the content of nutrients was low and typical for sandy soils.

Generally, investigated sandy soil creates favorable conditions for grassy sward development because of good water and air permeability. However, the scarcity of nutrients causes the need for constant mineral fertilization. Maintenance of stable sod requires a balance between input of nutrients into the soil and the uptake by cut vegetation. In the case of sports surfaces, the roles of nitrogen and phosphorous as well as potassium and calcium are emphasized [35-36]. For sport swards and airstrips, most important is the sod layer of $0-20 \mathrm{~cm}$, which contains the main root mass. For these purposes, the best parameters are demonstrated by the sands, which have the appropriate hardness and water permeability with simultaneous high quality of the sward [37].

Table 5. Density of the sward covering the runway.

\begin{tabular}{|c|c|c|c|c|c|}
\hline Season & Year & Mean & Minimum & Maximum & Coefficient of variation $(\%)$ \\
\hline \multirow{5}{*}{ Spring } & 2010 & 6.0 & 4 & 8 & 22.5 \\
\hline & 2011 & 6.1 & 4 & 7 & 17.8 \\
\hline & 2012 & 5.7 & 5 & 7 & 15.7 \\
\hline & 2013 & 7.3 & 5 & 9 & 15.7 \\
\hline & Mean & 6.3 & 4 & 9 & 19.9 \\
\hline \multirow{5}{*}{ Summer } & 2010 & 7.5 & 6 & 9 & 10.6 \\
\hline & 2011 & 6.5 & 1 & 9 & 30.4 \\
\hline & 2012 & 7.1 & 6 & 8 & 7.3 \\
\hline & 2013 & 7.1 & 6 & 8 & 9.4 \\
\hline & Mean & 7.0 & 1 & 9 & 16.6 \\
\hline \multirow{5}{*}{ Autumn } & 2010 & 7.8 & 5 & 9 & 15.7 \\
\hline & 2011 & 6.8 & 6 & 8 & 10.5 \\
\hline & 2012 & 6.8 & 5 & 8 & 12.2 \\
\hline & 2013 & 7.1 & 6 & 8 & 9.4 \\
\hline & Mean & 7.1 & 5 & 9 & 13.1 \\
\hline
\end{tabular}


Table 6. Color of the sward covering the runway.

\begin{tabular}{|c|c|c|c|c|c|}
\hline Season & Year & Mean & Minimum & Maximum & Coefficient of variation (\%) \\
\hline \multirow{4}{*}{ Spring } & 2010 & 4.8 & 4 & 7 & 41.1 \\
\cline { 2 - 6 } & 2011 & 4.1 & 1 & 6 & 30.7 \\
\cline { 2 - 6 } & 2012 & 5.0 & 4 & 8 & 37.0 \\
\cline { 2 - 6 } & 2013 & 5.1 & 1 & 8 & 33.5 \\
\hline \multirow{5}{*}{ Summer } & Mean & 4.8 & 1 & 7 & 24.5 \\
\cline { 2 - 6 } & 2010 & 5.2 & 4 & 9 & 20.2 \\
\cline { 2 - 6 } & 2011 & 6.5 & 4 & 9 & 20.1 \\
\cline { 2 - 6 } & 2013 & 6.8 & 4 & 7 & 23.0 \\
\hline \multirow{5}{*}{ Autumn } & Mean & 5.3 & 3 & 9 & 38.2 \\
\cline { 2 - 6 } & 2010 & 5.9 & 3 & 9 & 24.5 \\
\cline { 2 - 6 } & 2011 & 5.3 & 1 & 8 & 41.2 \\
\hline
\end{tabular}

The overwintering success, density, color, and overall quality of the sward covering the runway varied considerably across the experimental years. The greatest overwintering success ( 7.4 points on a nine-point scale) was noted in 2013, followed by 2010, whereas the lowest overwintering success was observed in the remaining years of the study (Table 4). Sward overwintering success was generally evaluated as average to good (5.9 points). According to Pronczuk et al. [38], overwintering success is determined by turf exposure to subzero temperatures, snow cover, and winter diseases. In this study, the analyzed parameter was probably also influenced by uneven soil compaction, prolonged snow cover, and wind erosion caused by aircraft motion.

Sward density on the runway varied across the seasons (Table 5). In spring, sward density was evaluated as satisfactory to good (6.3 points on the nine-point scale). The highest sward density was noted in 2013, whereas no significant differences were observed between the remaining years of the experiment. Sward density was higher in summer than in spring ( 7.0 points on a nine-point scale), but significant variations from unacceptable to very good were noted in 2011 (coefficient of variation of $30.4 \%$ ). Sward density was higher in fall than in spring (7.1 points on the nine-point scale). The runway was characterized by good sward cover in 2011-13, and by good to very good cover in 2010 . Sward density is one of the key quality parameters in grass airstrips. According to Harkot and Czarnecki [3], it is determined by fertilization, mowing, and irrigation. Laudanski et al. [39] noted that visual merit is determined by sward density in $70 \%$, color in $20 \%$, and leaf fineness in $10 \%$.
Sward composition is one of the most important features that determine the visual merit of lawns. It is also a measure of sward species' stability and adaptability to local habitat conditions [40].

Color is also a distinctive sward characteristic. According to Pronczuk et al. [38], color stability during the growing season and susceptibility to color change under exposure to environmental stressors are the key factors. Jankowski et al. [4] observed that swards with the highest visual merit were characterized by narrow leaf blades and a dark green color. In this study, sward color varied across the seasons (Table 6). It was dark green in summer (5.9 points on the nine-point scale) and fresh green in spring and fall (4.8-4.9 points). The least desirable, grayish-green color was observed in spring 2011 (coefficient of variation $-41.4 \%$ ). In summer, sward was most visually appealing (dark green) in 2011 and 2012, and it was characterized by a fresh green color in the remaining years of the study. In fall, the least appealing grayish-green color was noted in 2012 and 2013 (coefficient of variation - 41.2\%), and the sward took on a more attractive fresh green color in the remaining years of the experiment.

Sward density on the runway was satisfactory (minimum 5.0 points on the nine-point scale) in all years of the study, but its visual merit fell to 5.0 points already in the second year of the experiment (Table 7). According to Diesburg et al. [41], visual merit is not the most important parameter in low-input grass airstrips. The functionality of a grass runway is determined by sward resistance, even distribution on the surface, the ability to stabilize the soil, and limit soil erosion (dusting) and weed growth. The analyzed sward was characterized by the highest visual merit in the spring of 2013, and its appearance was 
Table 7. Overall quality of the sward covering the runway.

\begin{tabular}{|c|c|c|c|c|c|}
\hline Season & Year & Mean & Minimum & Maximum & Coefficient of variation $(\%)$ \\
\hline \multirow{5}{*}{ Spring } & 2010 & 5.3 & 4 & 7 & 18.4 \\
\hline & 2011 & 5.0 & 3 & 6 & 19.1 \\
\hline & 2012 & 5.3 & 4 & 6 & 14.6 \\
\hline & 2013 & 7.0 & 5 & 8 & 16.1 \\
\hline & Mean & 5.6 & 3 & 8 & 21.8 \\
\hline \multirow{5}{*}{ Summer } & 2010 & 5.6 & 4 & 7 & 17.8 \\
\hline & 2011 & 6.5 & 5 & 8 & 12.3 \\
\hline & 2012 & 5.7 & 4 & 8 & 25.3 \\
\hline & 2013 & 6.7 & 6 & 7 & 7.4 \\
\hline & Mean & 6.1 & 4 & 8 & 17.6 \\
\hline \multirow{5}{*}{ Autumn } & 2010 & 6.7 & 5 & 8 & 11.7 \\
\hline & 2011 & 6.0 & 5 & 8 & 15.9 \\
\hline & 2012 & 5.8 & 5 & 8 & 9.9 \\
\hline & 2013 & 6.3 & 6 & 7 & 7.8 \\
\hline & Mean & 6.2 & 5 & 8 & 12.4 \\
\hline
\end{tabular}

satisfactory in the remaining years of the study (Table 7). The visual merit of the sward was similar (satisfactory to good) in summer (6.1 points on the nine-point scale) and fall ( 6.2 points). Visual merit was determined by the applied management practices and weather conditions (coefficient of variation ranged from $7.4 \%$ to $25.3 \%$ in summer and from $7.8 \%$ to $15.9 \%$ in fall).

According to Donamski [22], the overall quality of the sward is determined by the interaction between its genotype and environmental factors. Sward density, color, and overall quality are indicative of plant health on the runway, and they enhance the local landscape. The sod formed by species of Festuca genus (F. ovina, F. rubra) with an admixture of Poa pratensis and Agrostis capillaris fulfilled the requirements of grassy airport surfaces in studied soil and climatic conditions, and can be recommended for other similar airports. It should be noted that on grassy surfaces exposed to a wide variety of extreme stress in the conditions of Minnesota (a northcentral U.S. state), Festuca ovina and F. rubra are also recommended [11].

\section{Conclusions}

1. The soil in the grass airstrip studied was composed of loose and slightly loamy sand, and it was classified into the very light soil category. High bulk density and relatively low total porosity point to high soil compaction.

2. Topsoil was characterized by slightly acidic and acidic $\mathrm{pH}$, and very low content of nitrate nitrogen, phosphorus, potassium, magnesium, copper, and zinc.
3. The sward covering the runway was characterized by moderate overwintering success, high density (in particular in fall), green and fresh green color, and satisfactory to good visual merit.

4. The overall quality of the sward covering the airstrip in Gryźliny was determined mainly by the physicochemical parameters of the soil, intensity of aviation operations (take-offs and landings), the applied management practices, and weather conditions during the study.

5. In studied climatic conditions, satisfactory grass cover can be established on light sandy soil, but regular balanced mineral fertilization is required. Festuca ovina and F. rubra (with admixture of Poa pratensis and Agrostis capillaries) can be recommended for field grassy airstrips.

\section{References}

1. GRZYBOWSKI W. Local airports. Przegląd Komunalny, 6 (177), 52-53. 2006 [In Polish].

2. O'QUINN B. Grass landing. Sport Aviation, 76, 2010.

3. HARKOT W., CZARNECKI Z. Usefulness of Polish lawn grass varieties for area sodding under difficult soil conditions. Folia Universitatis Agriculturae Stetinensis, 197 Agricultura 75, 117, 1999 [In Polish].

4. JANKOWSKI K., CIEPIELA G., JODEŁKA I., KOLCZAREK R. Comparing analysis of lawn mixtures cultivated in Podlasie region. Folia Universitatis Agriculturae Stetinensis, 197 Agricultura 75, 133, 1999 [In Polish].

5. RUTKOWSKA B., HARKOT W. Research, organisational and popularisation activities on the area of recreation and sports lawn establishment and management. Przegląd Nau- 
kowy. Inżynieria i Kształtowanie Środowiska, 11 (24), 15, 2002 [In Polish].

6. KOSMALA M. Modern methods of establishment sport field grass. Przegląd Komunalny 8 (155), 43, 2004 [In Polish].

7. GRABOWSKI K., GRZEGORCZYK S., KWIETNIEWSKI $\mathrm{H}$. Usefulness of 10 grasses mixtures for sowing on sport playing fields. Zeszyty Naukowe Uniwersytetu Przyrodniczego we Wrocławiu, 545, 95, 2006 [In Polish].

8. WOLSKI K., GAWEDZKI I., BARTMAŃSKI A., SOKOLSKA D., BARANOWSKI M. Suitability of turfgrass species, varieties and mixtures for turfing football grounds. Zeszyty Naukowe Uniwersytetu Przyrodniczego we Wrocławiu, Rolnictwo, 545 (88), 285, 2006 [In Polish].

9. PAWLUCZUK J., GRABOWSKI K. Impact of physical and chemical parameters of the subsoil on the botanical composition of sports field grass. J. Elem., 19 (2), 483, DOI: 10.5601/ jelem.2014.19.2.644. 2014

10. GRABOWSKI K., GŁOWACKA-GIL A., GRZEGORCZYK S., GRABOWSKA K. Utility values of extensive lawns fertilized with sewage sludge. Pol. J. Environ. Stud., 24 (5), 1959. DOI: 10.15244/pjoes/34708. 2015.

11. FRIELL J., WATKINS E., HORGAN B. Cool-season turfgrass species mixtures for roadsides in Minnesota. Ecol. Eng. 84, 579, 2015.

12. ISBELL F., CALGARNO V., HECTOR A., CONNOLLY J., HARPOLE W.S., REICH P.B., SCHERER-LORENZEN M., SCHMID B., TILMAN D., van RUIJVEN J., WEIGELT A., WILSEY B.J., ZAVALETA E.S., LOREAU M. High plant diversity is needed to maintain ecosystem services. Nature 477, 199, 2011.

13. ADKINS J., JASTROW J.D., MORRIS G.P., SIX J., de GRAAFF M.-A. Effects of switchgrass cultivars and intraspecific differences in root structure on soil carbon inputs and accumulation. Geoderma 262, 147, 2016.

14. KŘOVÁKOVÁ K., SEMERÁDOVÁ S., MUDROCHOVÁ M., SKALOŠ J. Landscape functions and their change - a review on methodological approaches. Ecol. Eng. 75, 378, 2015.

15. VANNUCCHI F., MALORGIO F., PEZZAROSSA B., PINI R., BRETZEL F. Effects of compost and mowing on the productivity and density of a purpose-sown mixture of native herbaceous species to revegetate degraded soil in anthropized areas. Ecol. Eng. 74, 60, 2015.

16. FISCHER L.K., VON DER LIPPE M., KOWARIK I. Urban grassland restoration: which plant traits make desires species successful colonizers? Appl. Veg. Sci. 16, 272, 2013.

17. Aviation Law of 3 July 2002 (Journal of Laws of 2006, No. 100, item 696, as amended). 2006 [In Polish].

18. Act of 30 April 2004 on the classification and registration of civilian airports (Journal of Laws of 31 May 2014). 2014 [In Polish].

19. VAN REEUWIJK L.P. Procedures for soil analysis. (Ed). Technical Paper 9. Wageningen, ISRIC, FAO. 2002.

20. SAPEK A., SAPEK B. Methods of chemical analysis of organic soils. Mat. Instr. IMUZ Falenty 115, 81, 1997 [In Polish].

21. OKRUSZKO H. The specific gravity of hydrogenic soils on the basis of mineral content. Wiadomości IMUZ, 10 (1), 47, 1971 [In Polish]

22. DOMAŃSKI P. Methods of studying economical value of cultivars of field crops. Agricultural plants. Turf (lawn) grasses. COBORU, Stupia Wielka, 1-35. 1998 [In Polish].
23. DERNOEDEN P.H., CAROLL M.J., KROUSE M.I. Mowing of three fescue species for low-maintenance turf sites. Crop Sci., 34 (6), 1645, 1994 [In Polish].

24. MINTENKO A.S., SMITH R.S., CATTANI D.I. Turfgrass evaluation of native grasses for the Northern Great Plains region. Crop Sci., 42, 2018, 2002.

25. Polish soil classification. Rocz. Glebozn. - Soil Sci. Ann., 62 (3), 1, 2011 [In Polish].

26. BROGOWSKI Z., KWASOWSKI W. An attempt of using soil grain size in calculating the capacity of water unavailable to plants. Soil Sci. Ann., 66 (1), 21. DOI: 10.1515/ssa2015-0015. 2015.

27. Particle size distribution and textural classes of soils and mineral materials - classification of Polish Society of Soil Science 2008. Rocz. Glebozn. - Soil Sci. Ann., 60 (2), 5 , 2009 [In Polish].

28. IUSS Working Group WRB. World Reference Base for Soil Resources 2014. World Soil Resources Reports No 106. FAO, Rome, 191, 2014.

29. GUILLARD K., FITZPATRICK R.J.M., BURDETT H. Matching subjective assessments of sod strength to quantitative measurements of peak shear force with predominately Kentucky bluegrass sod. HortScience 50 (8), 1248, 2015.

30. CHYBA J., KROULÍK M., KRIŠTOF K., MISIEWICZ P.A., CHANEY K. Influence of soil compaction by farm machinery and livestock on water infiltration rate on grassland. Agronomy Research 12 (1), 59, 2014.

31. BRADY N.C., WEIL R.R. The Nature and Properties of Soils. 14 ${ }^{\text {th }}$ Ed. Pearson Prentice Hall, 965, 2008.

32. KONSTANKIEWICZ K. Soil porosity, definitions, methods of determination. Problemy Agrofizyki, 47, 1, 1985 [In Polish].

33. AJAYI A.E., HORN R. Transformation of ex-arable land to permanent grassland promotes pore rigidity and mechanical soil resilience. Ecol. Eng. 94, 592, 2016.

34. Fertilizing recommendations. IUNG Puławy: 1-26, 1990 [In Polish].

35. HREVUŠOVÁ Z., HEJCMAN M., HAKL J., MRKVIČKA J. Soil chemical properties, plant species composition, herbage quality, production and nutrient uptake of an alluvial meadow after 45 years of N, P and K application. Grass Forage Sci. 70, 205, 2014.

36. MURPHY J.A., SCHMID C., CLARKE B.B. Annual bluegrass responses to potassium and calcium fertilization and soil pH. Turfgrass and Environmental Research Online 14 (2), 35,2015

37. FOLLIS C.C., ANDERSON S.H., FRESENBURG B.S., ERVIN E.H. Evaluation of sand-soil-compost root zones developed for athletic fields. Acta Hort. 783, 97, 2008

38. PROŃCZUK M., PROŃCZUK M., LAUDAŃSKI Z., PROŃCZUK S. Comparison of species and cultivars of Festuca ssp. in many-years of turf maintenance. Biul. IHAR, 225, 239, 2003 [In Polish].

39. LAUDAŃSKI Z., PROŃCZUK M., PROŃCZUK M. Proposition of turf characters synthesis for assessment of Festuca ssp. cultivars value. Biul. IHAR, 233, 181, 2004 [In Polish].

40. WYSOCKI CZ., STAWICKA J. Grasses in urban areas. Łąkarstwo w Polsce, 8, 227, 2005 [In Polish].

41. DIESBURG K.L., CHRISTIANS N.E., MOORE R., BRANHAM B., DANNEBERGER T.K., REICHER Z.I., VOIGT T., MINNER D.D., NEWMAN R. Species for lowinput sustainable turf in the U.S. Upper Midwest. Agron. J. 89 (4), 690, 1997. 